\title{
Spiroplasma floricola, a New Species Isolated from Surfaces of Flowers of the Tulip Tree, Liriodendron tulipifera $\mathrm{L}$.
}

\author{
R. E. DAVIS, ' I.-M. LEE, ${ }^{3}$ AND J. F. WORLEY ${ }^{2}$ \\ Plant Virology Laboratory, Plant Protection Institute, ' and Plant Hormone and Regulators Laboratory, \\ Plant Physiology Institute, ${ }^{2}$ Agricultural Research, Science and Education Administration, U.S. \\ Department of Agriculture, Beltsville, Maryland 20705, and Department of Plant Pathology, Cook College, \\ Rutgers University, New Brunswick, New Jersey $08304^{3}$
}

\begin{abstract}
Spiroplasma strains 23-6 and 27-31 from flowers of Liriodendron tulipifera L. (tulip tree) were indistinguishable from one another but were distinct from Spiroplasma citri and from members of serogroups other than the serogroup which contains $S$. citri. These two strains shared close to $100 \%$ deoxyribonucleic acid homology with one another, but only low homology $(<5 \%)$ with $S$. citri and other Spiroplasma strains. The acrylamide gel electrophoretic patterns of the cellular proteins of strains 23-6 and 27-31 appeared to be identical to each other, but they were distinct from the patterns of $S$. citri and various other strains. On the basis of serological and biochemical characteristics, we propose that strains 23-6 and 27-31 belong to a new species, Spiroplasma floricola, with strain 23-6 (= ATCC 29989) as the type strain. This new species grew well at 30 and $37^{\circ} \mathrm{C}$, in contrast to $\mathrm{S}$. citri, which grows poorly if at all at $37^{\circ} \mathrm{C}$. During log-phase growth in broth medium, $S$. floricola cells occurred as motile, helical, cell wallless filaments 0.15 to $0.2 \mu \mathrm{m}$ in diameter and 2 to about $5 \mu \mathrm{m}$ long. Classical "friedegg" Mycoplasma-type colonies were not observed on $1 \%$ agar medium. Instead, colonies had granular centers and diffuse borders and contained abundant, motile, helical cells. Growth was stimulated by cholesterol and inhibited by digitonin. Tests for catabolism of glucose, fructose, mannose, and arginine were positive. Tests for phosphatase activity were negative. The guanine-plus-cytosine contents of the deoxyribonucleic acids of strains 23-6 and 27-31 were close to $25 \mathrm{~mol} \%$.
\end{abstract}

Spiroplasmas were first recognized in and cultivated in vitro from diseased plants $(13,14,16$, 29). It is now apparent that spiroplasmas are widespread in nature and that some strains associated with plants probably do not cause plant disease $(7,9,10,12,22)$. Other Spiroplasma strains are associated with diseases in insects $(6$, 39,41 ) or are found in apparently healthy insects (17; R. E. McCoy, J. H. Tsai, and D. L. Thomas, Phytopathol. News 12: 217, 1978) and ticks (2, $5,25,30,35,36,43)$. Several distinct species are doubtlessly represented by the diverse strains now in culture in vitro, but only one species, Spiroplasma citri, has been recognized formally thus far (28).

Among the spiroplasmas from varied habitats are strains 23-6 and 27-31, which were isolated from surfaces of flowers of the tulip tree (Liriodendron tulipifera L.) $(9,10,12)$. Triply cloned strain 23-6 was shown to be serologically distinct from the honey bee Spiroplasma (strain AS 576) and from $S$. citri, and Davis suggested that strain 23-6 represented a new species (9). Subsequently, a scheme for the classification of Spiroplasma strains into serogroups and serological subgroups on the basis of membrane antigen reactivity was proposed (12). Estimations of deoxyribonucleic acid (DNA) base compositions and DNA-DNA homologies confirmed that the classification scheme reflected phylogenetic relationships (18) and supported the proposal (12) that the serogroups represented separate species. Strains 23-6 and 27-31 were serologically indistinguishable from one another and comprised a single subgroup in a major serogroup that exhibited no cross-reactions with other groups, and Davis et al. suggested that these two strains represented a single distinct species (12). In this paper we present gel electrophoretic analyses of cellular proteins and describe morphological, physiological, and biochemical properties of strains 23-6 and 27-31 which support our contention that these two strains belong to a new species.

\section{MATERIALS AND METHODS}

Spiroplasma strains. Strains 23-6 and 27-31 were isolated from surfaces of flowers of $L$. tulipifera $\mathrm{L}$. (9). Both of these strains were triply cloned by a procedure described previously (9). Strain 23-6 was deposited 
with the American Type Culture Collection as strain ATCC 29989. Other Spiroplasma strains used in this study included $S$. citri Maroc R8A2 (=ATCC 27556), S. citri C189 (=ATCC 27665), strains AS576 (=ATCC 29416) and G9, which were isolated from honey bees, and strains G1, SR9, and SR3 (=ATCC 33095), which were isolated from flowers $(10,12 ; \mathrm{R}$. E. Davis, Phytopathol. News 12:PO-7, 1978; R. E. Davis, J. F. Worley, T. B. Clark, and M. Moseley, Proc. Am. Phytopathol. Soc. 3:304, 1976). S. citri Maroc R8A2 and $S$. citri $\mathrm{C} 189$ were obtained from the American Type Culture Collection. Spiroplasma strain PPS1 was kindly furnished by R. E. McCoy (University of Florida Agricultural Research Center, Fort Lauderdale), who isolated it from flowers of Calliandra haematocephala (powder puff) (22). The remaining Spiroplasma strains were isolated in our laboratory in Beltsville, Md. The Acholeplasma laidlawii strain used was ATCC 23206.

Culture medium. Unless otherwise indicated, the spiroplasmas were cultivated in medium DSM4, which was similar to the medium of Liao and Chen $(3,20)$ and contained (per $100 \mathrm{ml}$ ) $1.5 \mathrm{~g}$ of PPLO broth base (Difco Laboratories, Detroit, Mich.), $8.0 \mathrm{~g}$ of sucrose, $10 \mathrm{ml}$ of inactivated $\left(30 \mathrm{~min}\right.$ at $\left.56^{\circ} \mathrm{C}\right)$ horse serum (Microbiological Associates, Bethesda, Md.), and 2.5 mg of phenol red, as described previously (9). Solid medium contained $1.0 \mathrm{~g}$ of Noble agar (Difco) per 100 $\mathrm{ml}$. All of the ingredients except horse serum were dissolved in distilled water to give a total volume of 90 $\mathrm{ml}$ of basal medium, the $\mathrm{pH}$ was adjusted to 7.4 , and the basal medium was sterilized by autoclaving for 15 min at $121^{\circ} \mathrm{C}$. Sterile horse serum was added aseptically to the autoclaved and cooled basal medium.

Morphology and ultrastructure. Dark-field optical microscopy was performed with a Zeiss model II photomicroscope. For ultrathin section electron microscopy, colonies in agar medium were treated by a method previously described (42) for microscopy of infected plant tissues. Freeze-etch electron microscopy was performed as described elsewhere (31).

Ultrafiltration. Samples from a 20 -h-old culture of strain 23-6 grown at $31^{\circ} \mathrm{C}$ were filtered through sterile membrane filters (pore size, $800,650,450,300$, or 200 $\mathrm{nm}$; Millipore Corp., Bedford, Mass.) in Swinney hypodermic adapters. Filtration was performed under conditions that uniformly gave a pressure of $116 \mathrm{~g} / \mathrm{cm}^{2}$ at the filter surface. The titers of the spiroplasmas in the filtrates were determined by duplicate plating of serial 10 -fold dilutions on solid agar medium.

Influence of serum on growth. The influence of serum concentration on growth was determined in broth media containing 10\% yeast extract (Flow Laboratories, Inc., Rockville, Md.) and $0,0.1,0.5,1,2,5$, 10 , or $20 \%$ inactivated horse serum. Portions of these media were seeded with a log-phase culture of strain 23-6 diluted with serum-free basal medium to give an initial titer of $3.4 \log$ colony-forming units per $\mathrm{ml}$ in each medium. After 16 and $26 \mathrm{~h}$ of incubation at $32^{\circ} \mathrm{C}$, the Spiroplasma titer at each serum concentration was determined by duplicate plating onto agar medium.

Growth inhibition by digitonin. Inhibition of growth by digitonin was determined in broth and agar media. In broth tests modified from the method of Razin and Schafer (26), the serum-free base of broth medium DSM4 was supplemented with $0.5 \%$ bovine serum albumin (fraction V; Sigma Chemical Co., St. Louis, Mo.), palmitic acid $(10 \mu \mathrm{g} / \mathrm{ml})$, and cholesterol (5 or $10 \mu \mathrm{g} / \mathrm{ml}$ ). Stock cholesterol was prepared as an ethanolic solution (27). Portions $(5 \mathrm{ml})$ of medium containing from 0 to $100 \mu \mathrm{g}$ of digitonin per $\mathrm{ml}$ were each seeded with $0.1 \mathrm{ml}$ of a 24 -h-old culture of strain 23-6 (diluted in medium containing $10 \mu \mathrm{g}$ of cholesterol per $\mathrm{ml}$ ) and incubated for 24 to $72 \mathrm{~h}$ at $31^{\circ} \mathrm{C}$. A change in color of phenol red to yellow indicated growth; the presence of helical Spiroplasma cells was confirmed by dark-field optical microscopy. A. laidlawii ATCC 23206 was used as a control. In tests on solid agar medium (15), medium DSM4 supplemented with 5 or $10 \%$ inactivated horse serum was used. Zones of inhibition were recorded after 5 to 7 days of incubation at 25,31 , or $37^{\circ} \mathrm{C}$. $S$. citri strain Maroc R8A2 and $A$. laidlawii ATCC 23206 were used as controls, and Spiroplasma strain SR3 was used as an additional test organism in the tests on solid agar medium.

Influence of cholesterol on growth. The influence of cholesterol on the growth of Spiroplasma strain 23-6 was determined by a broth method (27). Portions $(50 \mathrm{ml})$ of medium (serum-free DMS4 basal medium supplemented with $10 \%$ fresh yeast extract and $0.5 \%$ bovine serum albumin with or without $10 \mu \mathrm{g}$ of palmitic acid per ml, $0.01 \%$ Tween 80 , and varying amounts of cholesterol) were each seeded with $0.5 \mathrm{ml}$ of a 1:1,000 dilution (unsupplemented serum-free basal medium was used as the diluent) of a 24 -h-old culture of Spiroplasma strain 23-6 grown at $32^{\circ} \mathrm{C}$ in broth medium DSM4 containing serum (9). After $72 \mathrm{~h}$ of incubation at $32^{\circ} \mathrm{C}$, Spiroplasma cell protein was determined (27) by the method of Lowry et al. (21).

Catabolism of sugars and arginine and phosphatase activity. Tests of sugar catabolism were performed in medium D187C, which contained (per $100 \mathrm{ml}$ ) $2.0 \mathrm{~g}$ of tryptose (Difco), $0.5 \mathrm{~g}$ of $\mathrm{NaCl}, 2.5 \mathrm{mg}$ of phenol red, and a serum supplement. The serum supplement was either 5\% horse serum (GIBCO Laboratories, Grand Island, N.Y.) or 1\% PPLO serum fraction (Difco). This medium was supplemented with $0.5 \%$ glucose, $0.5 \%$ mannose, $0.5 \%$ fructose, $0.4 \% \mathrm{~L}$ arginine, or (in the case of strain AS576) $0.4 \%$ arginine plus $0.01 \%$ fructose (after Townsend [33]), which was sterilized by filtration (pore size, $220 \mathrm{~nm}$; Millipore). The final pH's of the resulting media were 7.1 to 7.3 . Portions $(2 \mathrm{ml})$ of medium were each seeded with 0.05 $\mathrm{ml}$ of a $1: 1,000$ dilution (diluted in medium D187C without substrates or serum) of a 24-h-old culture of Spiroplasmas cells, and these cultures were incubated for up to 7 days at $31^{\circ} \mathrm{C}$. A shift in the color of the $\mathrm{pH}$ indicator to yellow (acid in the case of the sugars) or to an alkaline reaction (deeper red or purple hue in the case of arginine or arginine plus fructose) was recorded as positive. Unseeded media and seeded media without substrate were used as controls.

Phosphatase activity was measured at 31 and $37^{\circ} \mathrm{C}$ by the method of Williams and Wittler (38) in solid $1 \%$ agar PPLO broth base medium (without phenol red) containing $5 \%$ inactivated horse serum and $0.01 \%$ phenolphthalein diphosphate. Plates were seeded in 
triplicate with $0.1 \mathrm{ml}$ of each of several 10 -fold dilutions of a 20 -h-old culture and were incubated at 31 or $37^{\circ} \mathrm{C}$. At 5,7 , and 9 days, one plate containing each dilution of inoculum with colonies was flooded with 5 $\mathrm{N} \mathrm{NaOH}$.

Polyacrylamide gel electrophoresis of cellular proteins. Cells were grown in broth medium for $20 \mathrm{~h}$ at $31^{\circ} \mathrm{C}$, harvested by centrifugation, and washed in a $12 \%$ sucrose solution. Protein was determined by the method of Lowry et al. (21). Proteins were solubilized by the method of Daniels and Meddins (8), and electrophoresis was performed on $7 \%$ polyacrylamide gel slabs in a vertical gel electrophoresis apparatus (Aquebogue Machine Shop, Aquebogue, N.Y.).

\section{RESULTS}

Morphological, cultural, and biochemical properties. Strains 23-6 and 27-31 were similar in morphological, cultural, and biochemical properties. We have described several characteristics of strain $23-6$ previously $(9,10)$. Cultures of strains 23-6 and 27-31 in broth medium contained motile, helical, filamentous cells during log-phase growth. Few or no rounded bodies were observed; no branched cells were seen. Helical cells were 0.15 to $0.2 \mu \mathrm{m}$ in diameter and 2 to about $5 \mu \mathrm{m}$ long in log-phase cultures (9). Freeze-etch electron microscopy revealed the particulate nature of the protoplasmic fracture faces of membranes of the Spiroplasma cells and showed a narrow, smooth band with few or no membrane-associated particles (Fig. 1). These characteristics are similar to those previously reported for the corn stunt Spiroplasma (R. L. Steere and R. E. Davis, Phytopathology 62:672, 1972).
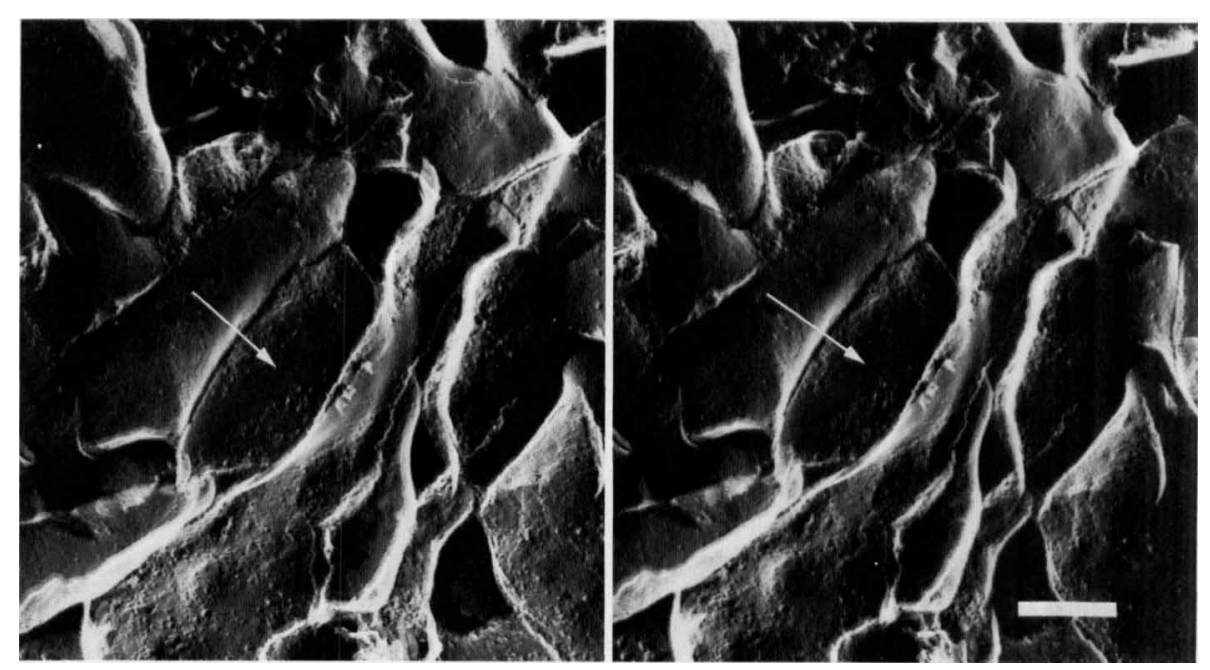

FIG. 1. Stereo electron micrographs of freeze-fractured and etched cells of Spiroplasma strain 23-6. Note narrow smooth band containing few or no membrane-associated particles (arrows). Bar $=200 \mathrm{~nm}$. (From $R$. L. Steere.)
Growth occurred at 22 to $37^{\circ} \mathrm{C}$, with optimal growth at about $34^{\circ} \mathrm{C}(9)$. This contrasted significantly with $S$. citri strains, which have been reported (28) to grow poorly, if at all, at 25 and $37^{\circ} \mathrm{C}$. Broth cultures developed marked turbidity. In ordinary broth medium, individual cells exhibited flexional and rotational motility, with little or not forward or reverse progress. In broth medium of elevated viscosity, the helical cells exhibited considerable translational locomotion, as reported previously $(9,10)$.

"Fried-egg" colonies were not observed on media solidified with agar. Instead, colonies were spreading and diffuse (9). Abundant, motile, helical Spiroplasma cells were seen in colonies examined by dark-field optical microscopy. Electron microscopy of ultrathin sections of colonies in agar revealed the three-layered limiting membrane of the Spiroplasma cells (Fig. 2) but failed to indicate the presence of any cell wall, envelope, second membrane, periplasmic fibrils, or flagellar structure (9).

Table 1 shows the results from the tests for catabolism of sugars and arginine. These results were similar whether media were supplemented with serum or with PPLO serum fraction. Strains 23-6 and 27-31 were strongly positive for catabolism of glucose, fructose, mannose, and arginine. Strains SR3 and SR9 were positive for catabolism of glucose, fructose, mannose, and arginine. Strain AS576 was positive for catabolism of glucose, fructose, and arginine but negative for catabolism of mannose. These findings agree with results reported previously (10). Strain PPS1 was strongly positive for catabolism 


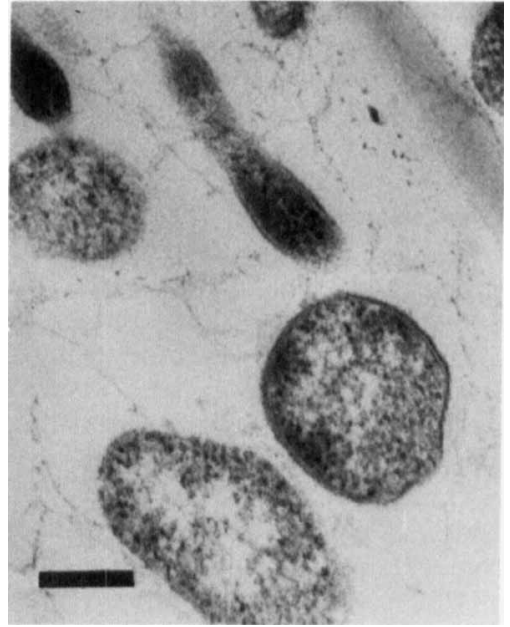

FIG. 2. Electron micrograph of ultrathin section of Spiroplasma strain 23-6 cells in colonies produced on agar medium. Bar $=200 \mathrm{~nm}$.

TABLE 1. Catabolism of glucose, fructose, mannose, and arginine by Spiroplasma strains 23-6, 27-31 $S R 3$, and $S R 9$ from flowers of L. tulipifera, strain AS576 from honey bees, and strain PPS1 from flowers of C. haematocephala

\begin{tabular}{lcccc}
\hline \multirow{2}{*}{$\begin{array}{c}\text { Spiroplasma } \\
\text { strain }\end{array}$} & \multicolumn{4}{c}{ Catabolism of: $^{a}$} \\
\cline { 2 - 5 } & Glucose & Fructose & Mannose & Arginine \\
\hline $23-6$ & $+^{b}$ & + & + & + \\
$27-31$ & + & + & + & + \\
SR3 & + & + & + & + \\
SR9 & + & + & + & + \\
AS576 & + & + & - & + \\
PPS1 & + & + & W & -
\end{tabular}

"Media contained $0.5 \%$ glucose, $0.5 \%$ fructose, $0.5 \%$ mannose, or $0.4 \%$ arginine, with the exception of the arginine medium for strain AS576, which contained $0.4 \%$ arginine and $0.01 \%$ frucose.

${ }^{b}+$, Positive; -, negative; $W$, weakly positive.

of glucose and fructose, weakly positive for catabolism of mannose, and negative for catabolism of arginine. The lack of arginine hydrolysis by strain PPS1 is in agreement with the results reported by McCoy et al. (22).

Both strain 23-6 and strain 27-31 were isolated originally in media lacking antibiotics (9), and they have been maintained in media free of antibiotics for at least 25 subcultures with no evidence of reversion to bacterial forms. They were strongly inhibited by tetracycline antibiotics and erythromycin but were relatively resistant to streptomycin $(10,11)$. Growth was not inhibited in media containing $10,000 \mathrm{U}$ of penicillin G per ml. Tests for phosphatase activity were negative. The guanine-plus-cytosine con- tents of the DNAs of these strains have been reported to be close to $25 \mathrm{~mol} \%$ (18).

Ultrafiltration. When filtered through membrane filters with average pore diameters of 800 , $650,450,300$, and $220 \mathrm{~nm}$, a triply cloned culture of strain 23-6 containing an estimated $6.7 \times 10^{8}$ colony-forming units per ml yielded $4.8 \times 10^{8}$, $3.8 \times 10^{8}, 3.7 \times 10^{8}, 3.6 \times 10^{8}$, and $2.8 \times 10^{8}$ colony-forming units per $\mathrm{ml}$, respectively.

Influence of serum on growth. Table 2 shows the results of a representative experiment in which we tested the influence of horse serum on the growth of Spiroplasma strain 23-6 in broth medium. Little or no growth was observed in medium containing no added serum, but growth was stimulated in medium containing as little as $0.1 \%$ horse serum supplement.

Growth inhibition by digitonin. Growth was inhibited by digitonin in all tests, a result consistent with a requirement for sterol $(15,26)$. In broth tests, the minimal inhibitory concentration of digitonin depended upon the inoculum concentration of Spiroplasma cells and the duration of incubation before the results were read (Table 3). Thus, the growth of strain 23-6 was inhibited at concentrations of digitonin of 15 to $35 \mu \mathrm{g} / \mathrm{ml}$ in media containing $10 \mu \mathrm{g}$ of cholesterol per $\mathrm{ml}$ (Table 3 ). Under the same conditions $A$. laidlawii ATCC 23206 was relatively resistant to digitonin; for example, when test results were read after $48 \mathrm{~h}$ of incubation, strain 23-6 was inhibited by $30 \mu \mathrm{g}$ of digitonin per $\mathrm{ml}$, but growth of A. laidlawii ATCC 23206 was evident at 100 $\mu \mathrm{g}$ of digitonin per $\mathrm{ml}$, the highest concentration tested. In a separate test, growth of strain 23-6 was inhibited by digitonin at concentrations of 20 and $30 \mu \mathrm{g} / \mathrm{ml}$ in media containing 5 and 10 $\mu \mathrm{g}$ of cholesterol per $\mathrm{ml}$, respectively, when the

TABLE 2. Influence of serum on the growth of Spiroplasma strain 23-6 in broth medium at $32^{\circ} \mathrm{C}^{a}$

\begin{tabular}{ccc}
\hline \multirow{2}{*}{ \% of horse serum } & \multicolumn{2}{c}{$\begin{array}{c}\text { Titer }(\log \mathrm{CFU} / \mathrm{ml}) \\
\text { for: }^{b}\end{array}$} \\
\cline { 2 - 3 } & $16 \mathrm{~h}$ & $26 \mathrm{~h}$ \\
\hline 0 & 3.1 & 3.8 \\
0.1 & 5.2 & 7.0 \\
0.5 & 5.7 & 7.6 \\
1 & 5.7 & 7.8 \\
2 & 5.9 & 8.0 \\
5 & 5.9 & 8.3 \\
10 & 5.9 & 8.3 \\
20 & 5.7 & 8.2 \\
\hline
\end{tabular}

${ }^{a}$ The medium contained (per $100 \mathrm{ml}$ ) $1.5 \mathrm{~g}$ of PPLO broth base (Difco), $8.0 \mathrm{~g}$ of sucrose, $2.5 \mathrm{mg}$ of phenol red, $10 \mathrm{ml}$ of fresh yeast extract (Flow), and 0 to $20 \mathrm{ml}$ of inactivated $\left(56^{\circ} \mathrm{C}, 30 \mathrm{~min}\right)$ horse serum.

${ }^{b} \mathrm{CFU}$, Colony-forming units. The titer at zero time was 3.4 log colony-forming units per $\mathrm{ml}$. 
results were read after 5 days of incubation at $31^{\circ} \mathrm{C}$.

Table 4 shows the zones of inhibition of growth on solid agar medium containing $10 \%$ serum. Colony formation by flower Spiroplasma strains 23-6 and SR3 and by $S$. citri Maroc R8A2 was inhibited strongly by digitonin at the growth-permitting temperatures of 25,31 , and $37^{\circ} \mathrm{C}$. A. laidlawii ATCC 23206 was inhibited only slightly (zone diameter, $\leq 1 \mathrm{~mm}$ ) under these conditions.

Influence of cholesterol on growth. Growth was minimal in serum-free broth medium supplemented with bovine serum albumin or with bovine serum albumin, palmitic acid, and Tween 80 but was enhanced by increasing concentrations of cholesterol (Table 5), in agreement with characteristics described previously (32) for the family Spiroplasmataceae.

TABLE 3. Inhibition of Spiroplasma strain 23-6 growth by digitonin in broth medium ${ }^{\prime \prime}$

\begin{tabular}{ccc}
\hline $\begin{array}{c}\text { Titer of Spiroplasma } \\
\text { cells at start of test } \\
(\mathrm{CFU} / \mathrm{ml})^{b}\end{array}$ & $\begin{array}{c}\text { Minimal inhibitory concentration of } \\
\text { digitonin }(\mu \mathrm{g} / \mathrm{ml}) \text { after incubation at } \\
31^{\circ} \mathrm{C} \text { for: }\end{array}$ \\
\cline { 2 - 3 } & $24 \mathrm{~h}$ & $72 \mathrm{~h}$ \\
\hline $3.6 \times 10^{6}$ & $\leq 25$ & $\leq 35$ \\
$3.6 \times 10^{5}$ & 20 & 30 \\
$3.6 \times 10^{4}$ & $\leq 20$ & 30 \\
$3.6 \times 10^{3}$ & $\leq 15$ & 30 \\
\hline
\end{tabular}

"The medium contained (per $100 \mathrm{ml}$ ) $1.5 \mathrm{~g}$ of PPLO broth base (Difco), $8.0 \mathrm{~g}$ of sucrose, $2.5 \mathrm{mg}$ of phenol red, $0.5 \%$ bovine serum albumin (fraction V), $10 \mu \mathrm{g}$ of palmitic acid per $\mathrm{ml}$, and $10 \mu \mathrm{g}$ of cholesterol per $\mathrm{ml}$.

${ }^{b} \mathrm{CFU}$, Colony-forming units. Broth medium was seeded with a 24 -h-old culture of Spiroplasma diluted with sterile broth to give initial titers of $3.6 \times 10^{3}$ to $3.6 \times 10^{6}$ colony-forming units per $\mathrm{ml}$ in media containing digitonin at concentrations of 0 to $50 \mu \mathrm{g} / \mathrm{ml}$.

TABLE 4. Inhibition by digitonin of growth of flower Spiroplasma strains 23.6 and SR3, of S. citri (Maroc R8A2), and of A. laidlawii ATCC 23206 on agar medium at 25,31 , and $37^{\circ} C^{a}$

\begin{tabular}{lcrr}
\hline \multirow{2}{*}{ Strain } & \multicolumn{3}{c}{$\begin{array}{l}\text { Zone of inhibition } \\
\text { the following incubation } \\
\text { temp: }\end{array}$} \\
\cline { 2 - 4 } & $25^{\circ} \mathrm{C}$ & $31^{\circ} \mathrm{C}$ & $37^{\circ} \mathrm{C}$ \\
\hline $23-6$ & 9.0 & 8.5 & 9.5 \\
SR3 & 8.5 & 8.0 & $\mathrm{ND}^{b}$ \\
S. citri Maroc R8A2 & $\mathrm{ND}$ & 14.0 & $\mathrm{ND}$ \\
A. laidlawii ATCC 23206 & 1.0 & $<1.0$ & $<1.0$ \\
\hline
\end{tabular}

"The medium contained (per $100 \mathrm{ml}) 1.5 \mathrm{~g}$ of PPLO broth base (Difco), $8.0 \mathrm{~g}$ of sucrose, $2.5 \mathrm{mg}$ of phenol red, $1.0 \mathrm{~g}$ of Noble agar (Difco), and $10 \mathrm{ml}$ of inactivated $\left(56^{\circ} \mathrm{C}, 30 \mathrm{~min}\right)$ horse serum. Results were recorded after 7 days of incubation.

${ }^{b} \mathrm{ND}$, not done.
Serological reactions. The results of serological tests of growth inhibition, organism deformation, and ring interface precipitin and microprecipitin tests in which purified membrane preparations were used as test antigens have been reported previously $(9,12)$. We observed no cross-reactions between strain 23-6 and any of the Spiroplasma strains listed in Table 6 when antigens or antisera to the latter or both were used $(9,12)$. Strains 23-6 and 27-31 were indistinguishable by growth inhibition and organism deformation tests but were distinct from the other Spiroplasma strains examined, including strains of $S$. citri.

Polyacrylamide gel electrophoresis. Polyacrylamide gel electrophoresis of cellular proteins from strains 23-6 and 27-31 gave identical patterns that were distinct from the pattern of strain SR3 (Fig. 3). The polyacrylamide gel electrophoresis protein pattern of strain 23-6 was also distinct from the patterns of $S$. citri and other Spiroplasma strains from plants and insects (Fig. 4).

\section{DISCUSSION}

Strains 23-6 and 27-31 from the surfaces of flowers clearly belong to the genus Spiroplasma, based on morphological, ultrastructural, growth requirement, and other characteristics described previously $(9,10,17,18)$ and evaluated more extensively here. We propose that strains 23-6 and 27-31 represent a single new species of Spiroplasma, based on similarities in properties of these two strains and on their distinctness from S. citri, the only Spiroplasma species formally proposed previously (28). That certain other strains now in cultivation may represent additional new species is strongly suggested by related work. Indeed, during the past several years investigations by several groups of researchers

TABLE 5. Influence of cholesterol on growth of Spiroplasma strain 23-6 in serum-free broth medium

\begin{tabular}{cc}
\hline Concn of cholesterol $(\mu \mathrm{g} / \mathrm{ml})$ & Concn of cell protein $^{u}$ \\
\hline $0^{b}$ & 0.03 \\
$0^{c}$ & 0.03 \\
0.2 & 0.16 \\
1 & 0.62 \\
5 & 0.86 \\
10 & 0.74 \\
20 & 0.75 \\
\hline
\end{tabular}

${ }^{a}$ Expressed in milligrams of protein per $50 \mathrm{ml}$ of culture.

${ }^{b}$ Serum-free medium supplemented with $0.5 \%$ bovine serum albumin.

' Serum-free medium was supplemented with $0.5 \%$ bovine serum albumin, $10 \mu \mathrm{g}$ of palmitic acid per $\mathrm{ml}$, and $0.01 \%$ Tween 80 . 
TABLE 6. Spiroplasma strains used in serological tests

\begin{tabular}{|c|c|c|c|}
\hline Serogroup & $\begin{array}{c}\text { Spiroplasma species or strain designa- } \\
\text { tion }\end{array}$ & Source from which originally isolated & Reference(s) \\
\hline $\mathrm{I}(\mathrm{A})^{a}$ & $\begin{array}{l}\text { S. citri Maroc R8A2 (=ATCC } \\
\text { 27556) }\end{array}$ & $\begin{array}{l}\text { Citrus (Citrus sinensis (L.) } \\
\text { Osbeck) }\end{array}$ & $14,23,24$ \\
\hline I (B) & AS576 (=ATCC 29416) & Honey bee & Davis et al. ${ }^{b}$ \\
\hline $\mathrm{I}(\mathrm{B})$ & GI & Surface of Bidens pilosa L. flower & Davis ${ }^{d}$ \\
\hline I (B) & BW & $\begin{array}{l}\text { Surface of basswood flower (Tilia } \\
\text { americana L.) }\end{array}$ & 10 \\
\hline I (C) & 1-747 $($ corn stunt; =ATCC 29051$)$ & Corn (Zea mays L.) & 4 \\
\hline II & $23-6(=$ ATCC 29989$)$ & Surface of $L$. tulipifera flower ${ }^{c}$ & $8,10,11$ \\
\hline II & $27-31$ & Surface of $L$. tulipifera flower & 10,11 \\
\hline III & SR3 (=ATCC 33095) & Surface of $L$. tulipifera flower & 10,11 \\
\hline III & SR9 & Surface of $L$. tulipifera flower & $8,10,11$ \\
\hline IV & $\begin{array}{l}\text { SMCA (suckling mouse cataract } \\
\text { spiroplasma; =ATCC } 29335)^{e}\end{array}$ & Rabbit tick & 26,27 \\
\hline
\end{tabular}

${ }^{a}$ Letters in parentheses are serological subgroups.

${ }^{b}$ Davis et al., Proc. Am. Phytopathol. Soc. 3:304, 1976.

${ }^{c}$ These spiroplasmas were presumably present in nectar.

${ }^{d}$ Davis, Phytopathol. News 12:PO-7, 1978.

${ }^{e}$ Growth inhibition test only.

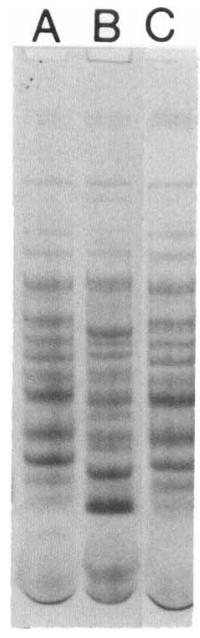

Fig. 3. Electrophoretic patterns of proteins from Spiroplasma strains 27.31 (lane A), SR3 (lane B), and 23-6 (lane C).

have shown that the cultured spiroplasmas comprise several types distinctly different from one another and from $S$. citri $(1,4,9,10,12,19,22-$ $24,34-36,40)$. Spiroplasmas isolated from flowers have been important elements in some of these investigations.

Spiroplasmas that occur on surfaces of flowers (presumably in nectar) were first isolated in culture from flowers of $L$. tulipifera $L$. (9). Shortly thereafter, other isolates were recovered from flowers of Magnolia grandiflora L. (7) and C. haematocephala (22). The isolates from tulip tree flowers included strains 23-6, 27-31, SR3, and SR9 $(9,12)$. Two new separate species were thought to be represented among these four

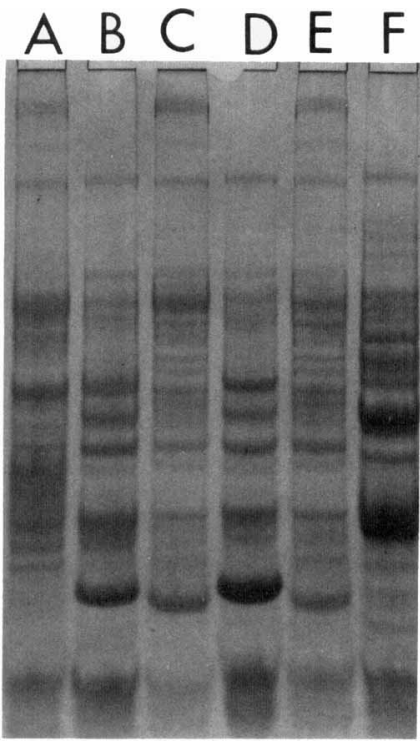

FIG. 4. Electrophoretic patterns of proteins from strains 1-747 (lane A), G1 (lane B), Maroc R8A2 (lane C), AS576 (lane D), C189 (lane E), and 23-6 (lane F).

strains $(9,10,12)$. In a scheme for the classification of Spiroplasma strains into serogroups and serological subgroups based on results from tests on membrane antigen reactivity (12), strains 23-6 and 27-31 were serologically indistinguishable and were placed in a single major serogroup (serogroup II). Flower Spiroplasma strains SR3 and SR9 were placed in another group (serogroup III), to which additional strains from flowers and insects have been added more recently $(25 \mathrm{a}, 34,37)$. The lack of crossreactions between serogroups II and III and 
between these groups and a separate group (serogroup I) containing S. citri was believed to be taxonomically significant (12). Work by others has further shown the feasibility of serological grouping of Spiroplasma strains (40; J. G. Tully, D. L. Williamson, D. L. Rose, and R. F. Whitcomb, Abstr. Annu. Meet. Am. Soc. Microbiol. 1979, G8, p. 83). For example, it has been shown that Spiroplasma strains OBMG and BNR1, which were isolated by T. B. Clark from magnolia and tulip tree flowers, respectively, and were found by polyacrylamide gel electrophoresis analyses of proteins to be identical to strain 23-6 (M. J. Daniels, personal communication), are distinct from Spiroplasma strains in other serological groups $(17,40)$.

The results from polyacrylamide gel electrophoresis studies of cellular proteins and DNA homology experiments among Spiroplasma strains agree well with the identifications and grouping based on serological reactions $(1,4,17$, $18,23,24$; M. J. Daniels, personal communication). For example, strains 23-6 and 27-31 have identical cellular protein electrophoretic patterns (see above) but are distinct from $S$. citri and from Spiroplasma strains belonging to other serogroups (Daniels, personal communication). Furthermore, strains 23-6 and 27-31 share close to $100 \%$ DNA homology with one another, but DNA homology between these strains and $S$. citri and other spiroplasmas was estimated at $\leq 5 \%$ (18). Spiroplasma groups and subgroups with strains separated on the basis of serology had the same identities as the groups and subgroups identified by reciprocal DNA homology studies (18). In this work, the guanine-plus-cytosine contents of the strain 23-6 and 27-31 DNAs were found to be close to $25 \mathrm{~mol} \%$, a value approximating the value for $S$. citri DNA (26 mol\%) $(1,28)$ but distinct from the value of 29 mol\% reported for the DNAs from the suckling mouse cataract agent $(1,4)$ and flower Spiroplasma strains SR3 and SR9 (18). In a separate study (17), DNAs from strains 23-6, OBMG, and BNR1 were also found to contain about $25 \mathrm{~mol} \%$ guanine plus cytosine and to share no homology with $S$. citri. The available data are consistent with the conclusion that Spiroplasma strains 23-6 and 27-31 are very similar or identical to one another and are distinct from $S$. citri and members of other serogroups.

In accordance with criteria proposed by the International Committee on Systematic Bacteriology Subcommittee on the Taxonomy of $\mathrm{Mol}$ licutes for separation of species (32), the distinction of strains 23-6 and 27-31 from $S$. citri by serology, gel electrophoresis of cellular proteins, and DNA homology indicates that strains 23-6 and $27-31$ belong to a single new species of Spiroplasma.

Based on the findings discussed above, we propose that Spiroplasma strains 23-6 and 27-31 be placed in a new species, for which we propose the name Spiroplasma floricola (L. $\mathrm{n}$. flora flower; L. v. colo dwell M. L. n. floricola flower dweller). Strain 23-6 (=ATCC 29989) is the type strain. This new species occurs in flower nectar and is characterized by motile, helical, wall-less cells 0.15 to $0.2 \mu \mathrm{m}$ in diameter and 2 to about 5 $\mu \mathrm{m}$ long during log-phase growth in DSM4 broth medium, by inhibition of growth by digitonin, by enhancement of growth by increasing concentrations of cholesterol, and by a DNA base composition of about $25 \mathrm{~mol} \%$ guanine plus cytosine (Table 7). The type strain and strain 27-31 are capable of growth at 22 to $37^{\circ} \mathrm{C}$ and grow rapidly at 30 to $37^{\circ} \mathrm{C}$, yielding turbid cultures in DSM4 broth medium and diffuse, spreading colonies on agar medium. These two strains catabolize glucose, fructose, mannose, and arginine but lack phosphatase activity.

\section{ACKNOWLEDGMENTS}

We gratefully acknowledge the excellent technical assist-

TABLE 7. Summary of several biological and biochemical properties of S. floricola

\begin{tabular}{|c|c|}
\hline Characteristic & Observation \\
\hline Cellular morphology & Helical \\
\hline Motility ... & $\begin{array}{l}\text { Rotational, flexional; } \\
\text { translational in } \\
\text { semisolid and viscous } \\
\text { media }\end{array}$ \\
\hline Catabolism of glucose ... & + \\
\hline Catabolism of fructose & + \\
\hline Catabolism of mannose & + \\
\hline Catabolism of arginine & + \\
\hline Phosphatase activity & - \\
\hline $\begin{array}{l}\text { Growth inhibition by } \\
\text { digitonin } \ldots \ldots\end{array}$ & + \\
\hline $\begin{array}{l}\text { Growth enhanced by } \\
\text { cholesterol } \ldots . . .\end{array}$ & + \\
\hline Culture turbidity & Heavy \\
\hline Colonies on agar medium & Diffuse, spreading \\
\hline Growth at $25^{\circ} \mathrm{C} \ldots \ldots$ & + \\
\hline Growth at $31^{\circ} \mathrm{C} \ldots \ldots$ & + \\
\hline Growth at $37^{\circ} \mathrm{C}$ & + \\
\hline Base composition of DNA & $\begin{array}{l}25 \text { mol\% guanine plus } \\
\text { cytosine }\end{array}$ \\
\hline $\begin{array}{l}\text { DNA homology with } S \text {. } \\
\text { citri } \ldots\end{array}$ & $<5 \%$ \\
\hline Type strain & 23-6 (=ATCC 29989) \\
\hline Source of type strain & $\begin{array}{l}\text { Surface (presumably } \\
\text { nectar) of flower of } L \text {. } \\
\text { tulipifera } \mathrm{L} \text {. }\end{array}$ \\
\hline
\end{tabular}


ance of L. K. Basciano, E. Erbe, M. H. Hale, B. L. Nivera, and C. J. Teuton in this work.

\section{REPRINT REQUESTS}

Address reprint requests to: $R$. E. Davis, Plant Virology Laboratory, Plant Protection Institute, U. S. Department of Agriculture, Beltsville, MD 20705.

\section{LITERATURE CITED}

1. Bové, J. M., and C. Saillard. 1979. Cell biology of spiroplasmas, p. 83-153. In R. F. Whitcomb and J. G. Tully (ed.), The mycoplasmas, vol. 3. Academic Press, Inc., New York.

2. Brinton, L. P., and W. Burgdorfer. 1976. Cellular and subcellular organization of the $277 \mathrm{~F}$ agent, a spiroplasma from the rabbit tick Haemaphysalis leporispalustris (Acari: Ixodidae). Int. J. Syst. Bacteriol. 26:554560.

3. Chen, T. A., and C. H. Liao. 1975. Corn stunt spiroplasma: isolation, cultivation, and proof of pathogenicity. Science 188:1015-1016.

4. Christiansen, C., G. Askaa, E. A. Freundt, and R. F. Whitcomb. 1979. Nucleic acid hybridization experiments with Spiroplasma citri and the corn stunt and suckling mouse cataract spiroplasmas. Curr. Microbiol. 2:323-326.

5. Clark, H. F., and L. B. Rorke. 1979. Spiroplasmas of tick origin and their pathogenicity, In R. F. Whitcomb and J. G. Tully (ed.), The mycoplasmas, vol. 3. Academic Press, Inc., New York.

6. Clark, T. B. 1977. Spiroplasma sp., a new pathogen in honey bees. J. Invertebr. Pathol. 29:112-113.

7. Clark, T. B. 1978. Honey bee spiroplasmosis: a new problem for beekeepers. Am. Bee J. 118:18-23.

8. Daniels, M. J., and B. M. Meddins. 1973. Polyacrylamide gel electrophoresis of mycoplasma proteins in sodium dodecyl sulfate. J. Gen. Microbiol. 76:239-242.

9. Davis, R. E. 1978. Spiroplasma associated with flowers of the tulip tree (Liriodendron tulipifera L.). Can J. Microbiol. 24:949-959.

10. Davis, R. E. 1979. Spiroplasmas: helical wall-free prokaryotes in diverse habitats, p. 59-64. In H. J. Su and R. E. McCoy (ed.), Proceedings of the Republic of ChinaUnited States Cooperative Science Seminar on Mycoplasma Diseases of Plants. National Science Council Symposium Series no. 1. National Science Council, Taipei.

11. Davis, R. E. 1981. Antibiotic sensitivities in vitro of diverse Spiroplasma strains associated with plants and insects. Appl. Environ. Microbiol. 41:329-333.

12. Davis, R. E., I.-M. Lee, and L. K. Basciano. 1979. Spiroplasmas: serological grouping of strains associated with plants and insects. Can. J. Microbiol. 25:861-866.

13. Davis, R. E., and J. F. Worley. 1973. Spiroplasma: motile, helical microorganism associated with corn stunt disease. Phytopathology 63:403-408.

14. Davis, R. E., J. F. Worley, R. F. Whitcomb. T. Ishijima, and R. L. Steere. 1972. Helical filaments produced by a mycoplasma-like organism associated with corn stunt disease. Science 176:521-523.

15. Freundt, E. A., B. E. Andrews, H. Erno, M. Kunze, and F. T. Black. 1973. The sensitivity of Mycoplasmatales to sodium-polyanetholsulfonate and digitonin. Zentralbl. Bakteriol. Parasitenkd. Infektionskr. Hyg. Abt. 1 Orig. Reihe A 225:104-112.

16. Fudl-Allah, A. E.-S. E., E. C. Calavan, and E. C. K. Igwegbe. 1972. Culture of a mycoplasmalike organism associated with stubborn disease of citrus. Phytopathology 62:729-731.

17. Junca, P., C. Saillard, J. Tully, O. Garcia-Jurado, J.-
R. Degorce-Dumas, C. Mouches, J.-C. Vignault, R. Vogel, R. McCoy, R. Whitcomb, J. Latrille, and J. M. Bové. 1980. Caracterisation de spiroplasmes isolés d'insectes et de fleurs de France continentale, de Corse et du Maroc. Proposition pour une classification des spiroplasmes. C. R. Acad. Sci. Ser. D 290:1209-1212.

18. Lee, I.-M., and R. E. Davis. 1980. DNA homology among diverse spiroplasma strains representing several serological groups. Can. J. Microbiol. 26:1356-1363.

19. Lei, J. D., H. J. Su, and T. A. Chen. 1979. Spiroplasmas isolated from green leaf bug, Trigonotylus ruficornis Geoffroy, p. 89-97. In H. J. Su and R. E. McCoy (ed.), Proceedings of the Republic of China-United States Cooperative Science Seminar on Mycoplasma Diseases of Plants. National Science Council Symposium Series no. 1. National Science Council, Taipei.

20. Liao, C. H., and T. A. Chen. 1977. Culture of corn stunt spiroplasma in a simple medium. Phytopathology 67: 802-807.

21. Lowry, O. H., N. J. Rosebrough, A. L. Farr, and R. J. Randall. 1951. Protein measurement with the Folin phenol reagent. J. Biol. Chem. 193:265-275.

22. McCoy, R. E., D. S. Williams, and D. L. Thomas. 1979. Isolation of mycoplasmas from flowers, p. 75-80. In $\mathrm{H}$. J. Su and R. E. McCoy (ed.), Proceedings of the Republic of China-United States Cooperative Science Seminar on Mycoplasma Diseases of Plants. National Science Council Symposium Series no. 1. National Science Council, Taipei.

23. Mouches, C., J. C. Vignault, J. G. Tully, R. F. Whitcomb, and J. M. Bové. 1979. Characterization of spiroplasmas by one- and two-dimensional protein analysis on polyacrylamide gels. Curr. Microbiol. 2:69-74.

24. Padhi, S. B., A. H. MeIntosh, and K. Maramorosch. 1977. Characterization and identification of spiroplasmas by polyacrylamide gel electrophoresis. Phytopathol. Z. 90:268-272.

25. Pickens, E. G., R. K. Gerloff, and W. Burgdorfer. 1968. Spirochete from the rabbit tick, Haemaphysalis leporispalustris (Packard). I. Isolation and preliminary characterization. J. Bacteriol. 95:291-299.

25a.Raju, B. C., G. Nyland, T. Meikle, and A. H. Purcell. 1981. Helical, motile mycoplasmas associated with flowers and honey bees in California. Can. J. Microbiol. 27: $249-253$.

26. Razin, S., and Z. Schafer. 1969. Incorporation of cholesterol by membranes of bacterial L-phase variants. J. Gen. Microbiol. 58:327-339.

27. Razin, S., and J. G. Tully. 1970. Cholesterol requirement of mycoplasmas. J. Bacteriol. 102:306-310.

28. Saglio, P., M. L'Hospital, D. Laflèche, G. Dupont, J. M. Bové, J. G. Tully, and E. A. Freundt. 1973. Spiroplasma citri gen. and sp. n: a mycoplasma-like organism associated with "stubborn" disease of citrus. Int. J. Syst. Bacteriol. 23:191-204.

29. Saglio, P., D. Laflèche, C. Bonissol, and J. M. Bové. 1971 Isolement, culture et observation au microscope électronique des structures de type mycoplasme associeés à la maladie du stubborn des agrumes et leur comparison avec les structures observeés dans la cas de la maladie du greening des agrumes. Physiol. Veg. 9: 569-582.

30. Stalheim, O. H. V., A. E. Ritchie, and R. F. Whitcomb. 1978. Cultivation, serology, ultrastructure, and viruslike particles of spiroplasma 277 F. Curr. Microbiol. 1: $365-370$.

31. Steere, R. L. 1973. Preparation of high-resolution freezeetch, freeze-fracture, frozen-surface, and freeze-dried replicas in a single freeze-etch module, and the use of stereo electron microscopy to obtain maximum information from them, p. 223-255. In E. Benedetti and P. Favard (ed.), Freeze-etching techniques and applica- 
tions. Societe Francaise de Microscopie Electronique, Paris.

32. Subcommittee on the Taxonomy of Mollicutes. 1979. Proposal of minimal standards for description of new species of the class Mollicutes. Int. J. Syst. Bacteriol. 29:172-180.

33. Townsend, R. 1976. Arginine metabolism by Spiroplasma citri. J. Gen. Microbiol. 94:417-420.

34. Tully, J. G., D. L. Rose, O. Garcia-Jurado, J. C. Vignault, C. Saillard, J. M. Bové, R. E. McCoy, and D. L. Williamson. 1980. Serological analysis of a new group of spiroplasmas. Curr. Microbiol. 3:369-372.

35. Tully, J. G., R. F. Whitcomb, H. F. Clark, and D. L. Williamson. 1977. Pathogenic mycoplasmas: cultivation and vertebrate pathogenicity of a new spiroplasma. Science 195:892-894.

36. Tully, J. G., R. F. Whitcomb, D. L. Williamson, and H. F. Clark. 1976. Suckling mouse cataract agent is a helical wall-free prokaryote (spiroplasma) pathogenic for vertebrates. Nature (London) 259:117-120.

37. Vignault, J. C., J. M. Bové, C. Saillard, R. Vogel, A. Farro, L. Venegas, W. Stemmer, S. Aoki, R. McCoy, A. S. Al-Beldawi, M. Larue, O. Tuzeu, M. Ozsan, A. Nhami, M. Abassi, J. Bonfils, G. Moutous, A. Fo, F. Poutiers, and G. Viennot-Bourgin. 1980. Mise en culture de spiroplasmes à partir de ma- tériel végètal et d'insectes provenant de pays circummediterranéens et du Proche-Orient. C. R. Acad. Sci. Ser. D 290:775-778.

38. Williams, C. O., and R. G. Wittler. 1971. Hydrolysis of esculin and phosphatase production by members of the order Mycoplasmatales which do not require sterol. Int. J. Syst. Bacteriol, 21:73-77.

39. Williamson, D. L., and D. F. Poulson. 1979. Sex ratio organisms (spiroplasmas) of Drosophila, p. 175-208. In R. F. Whitcomb and J. G. Tully (ed.), The mycoplasmas, vol. 3. Academic Press, Inc., New York.

40. Williamson, D. L., J. G. Tully, and R. F. Whitcomb. 1979. Serological relationships of spiroplasmas as shown by combined deformation and metabolism inhibition tests. Int. J. Syst. Bacteriol. 29:345-351.

41. Williamson, D. L., and R. F. Whitcomb. 1974. Helical, wall-free prokaryotes in Drosophila, leafhoppers, and plants. Colloq. INSERM 33:282-290.

42. Worley, J. F. 1970. Possible replicative forms of a mycoplasma-like organism and their location in aster yellows diseased Nicotiana and aster. Phytopathology 60: 284-292.

43. Zeigel, R. F., and H. F. Clark. 1974. Electron microscopy of the suckling mouse cataract agent: a noncultivable animal pathogen possibly related to mycoplasma. Infect. Immun. 9:430-443. 